\title{
A REPLACEMENT NAME FOR THORIA ZACHARDA (ACARIFORMES: PROSTIGMATA: EUPODOIDEA)
}

\author{
Filippo Ceccolini ${ }^{1}$ and Fabio Cianferoni ${ }^{2,1^{*}}$
}

\author{
${ }^{1}$ Natural History Museum, University of Florence, Florence, Italy \\ ${ }^{2}$ Research Institute on Terrestrial Ecosystems, National Research Council of Italy (CNR), \\ Sesto Fiorentino (Florence), Italy \\ *corresponding author; e-mail: fabio.cianferoni@cnr.it
}

\begin{abstract}
A genus name of Trombidiformes Prostigmata turned out to be a junior homonym (preoccupied by an insect name) and a replacement name is proposed: Sigthoria nom.n. pro Thoria Zacharda, 1980 nec Stål, 1864. Two new combinations (comb.n.) are provided.
\end{abstract}

KEY WORDS: Acari, combinatio nova, nomen novum, Eupodoidea.

DOI: 10.21684/0132-8077-2021-29-2-267-268

\section{INTRODUCTION}

In the present work, a genus name of Acariformes, which is a junior homonym, is replaced according to the International Code of Zoological Nomenclature (ICZN 1999).

The classification adopted is based on Zhang et al. (2011).

\section{REPLACEMENT NAMES}

Order Trombidiformes Reuter, 1909

Suborder Prostigmata Kramer, 1877

Infraorder Eupodina Krantz, 1978

Superfamily Eupodoidea Koch, 1842

Family Rhagidiidae Oudemans, 1922

Zacharda (1980: 747) established the new genus Thoria to include the new species $T$. brevisensilla and to accommodate the known species Rhagidia uniseta Thor, 1909 ( $=R$. crassipes Schweizer and Bader, 1963). This mite genus name is currently accepted (Abou-Awad 1985; IRMNG 2021).

However, Thoria Zacharda is a junior homonym, which is invalid. Indeed, this name is preoccupied by another one published by Stål (1864: 90) who had already used it within Hemiptera Pentatomidae. Thoria Stål is still accepted (Rider 2015). According to ICZN (1999, arts. 60.1, 60.2), since no available synonym for Thoria Zacharda is available, a replacement name is needed. Therefore, we propose Sigthoria Ceccolini and Cianferoni nom.n.

Etymology. The new name follows the original dedication by Zacharda (1980) to the Norwegian entomologist Sig Thor (1856-1937), with the addition of his first name. Feminine gender.

\section{SYSTEMATICS}

Genus Sigthoria Ceccolini and Cianferoni nom.n. Species Sigthoria brevisensilla (Zacharda, 1980) comb.n. $=$ Thoria brevisensilla Zacharda, 1980 (type species)

Sigthoria uniseta $($ Thor, 1909) comb.n. $=$ Thoria uniseta $($ Thor, 1909) $=$ Rhagidia uniseta Thor, $1909=$ Rhagidia crassipes Scheizer and Bader, 1963

\section{ACKNOWLEDGEMENTS}

We are grateful to Andrei Tolstikov (Tyumen State University, Russia) and to two anonymous reviewers for their helpful recommendations. We kindly thank Surajit Sur (Department of Zoology, Muralidhar Girls' College, Kolkata, India) and Samiran Chakrabarti (Department of Zoology, Vidyasagar College, Kolkata, India) for providing literature.

\section{REFERENCES}

Abou-Awad, B. 1985. The rhagidiid mites of Egypt (Acari: Eupodoidea: Rhagidiidae). Acarologia, 26(3): 253-259.

ICZN-International Commission on Zoological Nomenclature. 1999. International Code of Zoological Nomenclature. $4^{\text {th }}$ Edition. The International Trust for Zoological Nomenclature, London, XXIX $+306 \mathrm{pp}$.

IRMNG-The Interim Register of Marine and Nonmarine Genera 2021. Date of access: July 26, 2021. https://www.irmng.org

Rider, D. 2015. Pentatomoidea Home page. Date of access: February 26, 2015. https://www.ndsu.edu/ pubweb/ rider/Pentatomoidea/

Stål, C. 1864. Hemiptera africana. Tomus primus. Officina Norstediana, Stockholm, 256 pp. 


\section{F. Ceccolini and F. Cianferoni}

Zacharda, M., 1980. Soil mites of the family Rhagidiidae (Actinedida: Eupodoidea). Morphology, Systematics, Ecology. Acta Universitatis Carolinae. Biologica, 1978 (5-6): 498-785.

Zhang, Z.-Q., Fan, Q.-H., Pesic, V., Smit, H., Bochkov, A. V., Khaustov, A.A., Baker, A., Wohlt- mann, A., Wen, T., Amrine, J.W., Beron, P., Lin, J., Gabrys, G. and Husband, R. 2011. Order Trombidiformes Reuter, 1909. In: Z.-Q. Zhang (Ed.). Animal biodiversity: An outline of higher-level classification and survey of taxonomic richness. Zootaxa, 3148: 129-138. 